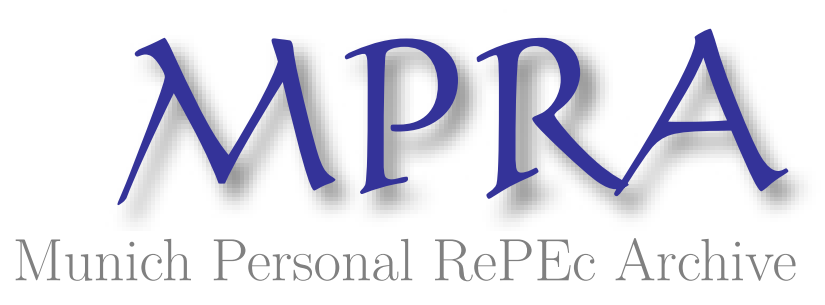

\title{
Do mergers create or destroy value? Evidence from unsuccessful mergers
}

Cole, Rebel and Fatemi, Ali and Vu, Joseph

DePaul University

October 2006

Online at https://mpra.ub.uni-muenchen.de/4717/

MPRA Paper No. 4717, posted 05 Sep 2007 UTC 


\title{
Do mergers create or destroy value? Evidence from unsuccessful mergers
}

\author{
Rebel A. Cole* \\ Department of Finance \\ DePaul University \\ Chicago, IL 60604 \\ rcole@depaul.edu \\ Ali Fatemi \\ Department of Finance \\ DePaul University \\ Chicago, IL 60604 \\ fatemi@depaul.edu \\ Joseph Vu \\ Department of Finance \\ DePaul University \\ Chicago, IL 60604 \\ 312-362-5121 \\ jvu@depaul.edu
}

DRAFT: October 2006

Please do not quote with permission of authors.

* Corresponding author: Tel.: 1-312-362-6887.

Acknowledgements: We are grateful to the College of Commerce at DePaul University for research support. We thank Irina Krop for assistance in collection and preparation of the data. We appreciate comments from participants at the 2006 Annual Meeting of the Financial Management Association held in Salt Lake City, Utah, where this paper was presented. 


\begin{abstract}
:
In this study, we examine unsuccessful takeover attempts for new evidence on whether mergers create or destroy value for acquirers and targets. We contribute to the literature in three important areas. First, we contribute to the literature on signaling by investigating whether a takeover attempt signals investors about the quality of firm management as well as the quality of the specific firm investment under consideration. We find that bid announcement returns are partially, but not completely, reversed by termination announcement returns, evidence that the merger proposal itself contains information about the value of the bidding firm. Second, we contribute to the literature on the value of diversification by examining how merger bids and terminations affect the relative values of bidders attempting diversifying and focusing takeovers. Our evidence enables us to differentiate between the synergistic and agency views of mergers. We find significant differences in the responses of firms attempting focusing versus diversifying mergers. The reversal of bid announcement returns by termination announcement returns is significantly different for focusing and diversifying firms. There is no reversal for diversifying firms while there is a partial reversal for focusing firms. This provides evidence in support of both the synergistic and agency views of mergers. Synergies are evident in focusing mergers while agency costs are evident in diversifying mergers. Third, we contribute to the literature on the valuation effects of mergers by using data from the 1991-2000 period to re-examine the important topic of who wins and who loses when mergers are terminated. Previous research examining terminated mergers has relied exclusively upon data from the $1980 \mathrm{~s}$.
\end{abstract}

\title{
Keywords: diversification, focus, merger, signaling, terminated merger JEL Classification: G14, G34
}




\section{Do mergers create or destroy value? Evidence from unsuccessful mergers}

\section{Introduction}

The market for corporate control is one of the fundamental mechanisms of corporate governance by which firm managers are induced to act in the best interests of widely dispersed shareholders. When firm management fails to maximize shareholder value by a sufficiently large degree, prospective gains induce outsiders to threaten or actually take steps to replace incumbent management. The actions of these outsiders lead to increased firm value as shareholders revalue the firm's future cash flows under new management or under better stewardship by existing management.

As Denis and McConnell (2003) point out, the market for corporate control has a "dark side," as well. Managers may engage in takeovers ${ }^{1}$ to maximize personal utility rather than shareholder value. In many cases, these takeovers are negative net-present-value (NPV) projects that decrease, rather than increase, shareholder wealth.

Do takeovers create or destroy value for would-be acquirers? Theory offers competing answers, leading researchers to turn to empirical studies for an answer. Numerous studies have used standard event-study methodology to examine the effects of successful takeovers and come up with conflicting evidence. ${ }^{2}$ The purpose of the proposed research is to take a different tack, by examining unsuccessful takeover attempts for new evidence on whether mergers create or destroy value for acquirers and targets.

In general, event studies of successful mergers find that targets of takeover attempts realize positive and significant excess returns around the announcement dates of the takeovers.

\footnotetext{
${ }^{1}$ We use the terms "takeover," "merger" and "acquisition" interchangeably in this proposal.

${ }^{2}$ See Bruner (2002) for a recent review of this literature.
} 
Estimates of the targets' gains are quite large, ranging from around 10\% to 30\%. Evidence on the returns to acquirers is quite mixed. One group of studies finding significantly negative returns in the range of $-1 \%$ to $-3 \%$; a second group finding significantly positive returns in the range of $1 \%$ to $7 \%$; and a third group finds no significant abnormal returns.

This inconclusive body of evidence on the returns to acquirers is not surprising. Theoretically, mergers create value by creating operating synergies, typically in the form of economies of scale or economies of scope. Economies of scale are most likely to be realized when firms engaged in the same line of business combine operations, i.e., in horizontal mergers. Economies of scope are most likely to be realized when firms in the same chain of supply combine operations, i.e., in vertical mergers.

When firms in unrelated businesses combine operations, i.e., in conglomerate mergers, there is less theoretical reason for value creation. Many researchers have theorized that financial synergies are created in conglomerate mergers. ${ }^{3}$ By reducing the variability of the combined firm's cash flows through diversification, the merger supposedly enables the resulting firm to borrow at lower rates than either of the two merging firms, thereby lowering its weighted average cost of capital. Another advantage is the tax treatment of income whereby profits generate a tax liability but losses do not generate a tax credit (Madj and Meyers 1987). Diversified firms can avoid this asymmetry to some degree by pooling gains and losses across business segments.

Agency theory, however, suggests that mergers, in general, and conglomerate mergers, in particular, result from principal-agent conflicts between shareholders seeking to maximize their

\footnotetext{
${ }^{3}$ See, for example, Levy and Sarnat (1970), Lewellen (1971), Lintner (1971), Weston and Mansinghka (1971), Melnik and Pollatschek (1973), Williamson (1975), Amihud and Levi (1981), Stapleton (1982), and Amihud, Dodd and Weinstein (1986)).
} 
wealth and firm managers seeking a larger empire or a less-risky firm (Jensen 1986). Because firm size is a fundamental determinant of executive compensation (Baker, Jensen and Murphy 1988; Jensen and Murphy 1990), managers have strong incentives to make acquisitions that increase firm size, even at the expense of shareholder wealth. Similarly, firm managers benefit from mergers that provide less risky cash flows through diversification, as their job security is enhanced when the likelihood of financial distress is reduced.

How does this explain the contradictory findings regarding returns to bidders? The synergistic view of mergers suggests that horizontal and vertical mergers create shareholder value, but that conglomerate mergers may not. The agency view of mergers suggests that all mergers are likely to destroy value, but that conglomerate mergers and mergers where the acquirer has exceptional performance, substantial free-cash flow and unused debt capacity are especially suspect. The synergistic view supports the group of studies finding positive abnormal returns for acquirers, whereas the agency view supports the group of studies finding negative abnormal returns for acquirers.

In this study, we contribute to the literature in three important areas. First, we contribute to the literature on signaling by investigating whether a takeover attempt signals investors about the quality of firm management as well as the quality of the specific firm investment under consideration. If changes in value around bid announcements are not reversed around termination announcements, then these net changes in value provide evidence that mergers signal to investors about the quality of management as well as about the value of the proposed acquisition. We find that bid announcement returns are partially, but not completely, reversed by termination announcement returns, evidence that the merger proposal itself contains information about the value of the bidding firm. 
Second, we contribute to the literature on the value of diversification by examining how merger bids and terminations affect the relative values of bidders attempting diversifying and focusing takeovers. Our evidence enables us to differentiate between the synergistic and agency views of mergers. We find significant differences in the responses of firms attempting focusing versus diversifying mergers. The reversal of bid announcement returns by termination announcement returns is significantly different for focusing and diversifying firms. There is no reversal for diversifying firms while there is a partial reversal for focusing firms. This provides evidence in support of both the synergistic and agency views of mergers. Synergies are evident in focusing mergers while agency costs are evident in diversifying mergers.

Third, we contribute to the literature on the valuation effects of mergers by using data from the 1991-2000 period to re-examine the important topic of who wins and who loses when mergers are terminated. Previous research examining terminated mergers has relied exclusively upon data from the 1980s. Andrade, Mitchell and Stafford (2001) provide evidence of significant differences in these two waves of mergers, including the decline in the portion of hostile takeovers and increased use of stock as the method of payment during the 1990s.

\section{Literature Review}

The empirical evidence on conglomerate firms is consistent with agency theory. More specifically, these authors attempt to test the "inefficient investment" hypothesis, which posits that diversified firms invest too much in segments that perform poorly and too little in segments that perform well. Lang and Stulz (1994), Comment and Jarrell (1995), Berger and Ofek (1995), Servaes (1996), Lamont (1997), Shin and Stulz (1998), Rajan, Servaes and Zingales (2000) and Lamont and Polk (2002) each find that conglomerate firms sell at a discount relative 
to firms operating in a single industry and attribute this to agency costs. In general, these firms examine the investments of conglomerates by SIC codes and compare those investments with industry values of Tobin's Q measured across single-segment firms.

Maquieria, Megginson and Nail (1998) analyze wealth changes around stock-for-stock mergers announced during 1963-96 period. They find that bidders in non-conglomerate mergers reap significant wealth gains while bidders in conglomerate mergers experience significant wealth losses. Overall, they find evidence that non-conglomerate mergers create real operating synergies but that conglomerate mergers do not appear to create financial synergies. Delong (2001) examines bank mergers, classifying them by focus along geography and activity as proxied by stock-return clustering. He find that mergers of two banks in the same geographic region or involved in the same activities increase the bidder's value by $2 \%$ to $3 \%$ more than other types of bank mergers. ${ }^{4}$

A number of studies have examined the accounting performance of firms involved in mergers, the two most widely known being Ravenscraft and Scherer (1989) and Healy, Palepu and Ruback (1992). Ravenscraft and Scherer examine firm profitability by line of business and find that targets decline in profitability post-merger. They conclude from this evidence that mergers destroy firm value. Healy, Palepu and Ruback (1992) examine the combined industryadjusted operating performance of fifty largest mergers occurring during 1979-84 during the three years before and after the merger. They find that industry-adjusted performance increases significantly during post-merger period.

\footnotetext{
${ }^{4}$ Other studies finding evidence that increased focus benefits shareholders include Morck, Shleifer and Vishny (1990), Bhagat, Shleifer and Vishny (1990), Healy, Palepu, and Ruback (1992), Lang and Stulz (1994), and Servaes (1996).
} 
In general, the above cited studies examine successful takeovers. In practice, there also have been a number of takeover attempts that failed. To fully understand how mergers affect firm value, it is insightful to examine evidence from these failed takeover attempts.

In this study, we provide such an analysis. We have identified 220 pairs of firms that were involved in failed takeover attempts during the period 1992-2001, and classified each merger as diversifying (conglomerate) or focusing (horizontal or vertical) based upon the firms' two-digit standard industrial classification SIC code. We then use standard event-study methodology to estimate the excess returns around the announcements of both the takeover bid and the subsequent termination of the takeover bid. By comparing the excess returns around the announcements of the merger bids to those around the announcement of the merger terminations, we provide new evidence regarding signaling theory, i.e., whether mergers attempts signal the quality of firm management as well as the quality of firm investment. By comparing the excess returns to focusing versus diversifying mergers, we are able provide new evidence on the synergistic versus agency views of mergers.

There are a number of studies that have examined failed takeovers, but most of these are now quite dated and analyze takeover attempts that occurred during the merger wave of the 1980s. Around the announcements of merger terminated during the 1970s, Dodd (1980) finds negative excess returns for bidding firms but positive excess returns for target firms, if the target firm initiates the termination. Both Dodd and Ruback (1977) and Bradley (1980) examine tender offers and find that the value of target firms remain above pre-offer levels after the offers are cancelled. Bradley, Desai and Kim (1983) find negative excess returns for bidding firms around the announcements of failed tender offers during the 1970s. 
Davidson, Dutia and Cheng (1989) examine 163 failed mergers during the 1976-86 period. They find results similar to Dodd (1980); negative excess returns for bidders and positive excess returns for targets initiating the terminations. Denis and Serrano (1996) analyze unsuccessful takeovers during the 1983-89 period and find high management turnover following termination of the takeover attempt.

Chang and Suk (1998) examine 279 failed mergers from 1982-90; around merger terminations, they find positive excess returns for bidders offering stock and negative excess returns for bidders offering cash, each significant at the .10 level. They also find that excess returns are positive when the bidder initiates the termination and insignificant when the target initiates the termination.

Safiedeine and Titman (1999) examine a sample of 573 targets of unsuccessful takeovers that occurred during the 1982-1991 period, and find that targets terminating attempted takeovers suffer negative excess returns of 5.14\% around the announcement date of the termination.

Although most of these studies document that bidding firms suffer negative excess return at the time of the merger termination, none of these studies can explain under what circumstances bidding firms are expected to have negative returns.

\section{Data}

To conduct this study, we collected four different types of data: daily stock return data, annual data identifying firms by industry, annual performance data on firm performance and condition and data on the dates when mergers and merger terminations were announced in the financial press. We obtained daily stock-return data from CRSP and annual accounting data as well as data on standard industry classification (SIC) codes from Compustat. To identify the 
dates on which mergers and merger terminations were announced, we searched Mergerstat Review, the Wall Street Journal Index and the Lexis-Nexis database. From these three sources, we identified a total of 220 merger terminations during the period from January 1991 through December 2000. To be included in our sample, both the acquirer and target had to be publicly traded and have data available from both Compustat and CRSP.

Table 1 reports the distribution of our sample by year, type of merger and form of payment, while Table 2 reports sample composition and descriptive statistics. The majority of firms are involved in horizontal mergers (127 of 220). Almost half proposed using stock to finance their acquisitions (102 of 220). There are only 35 proposed conglomerate mergers and only 52 proposed cash transactions. The mean and median times between the bid and termination announcements (not shown in Table 1) were 73 and 53 days, respectively, with a range of 1 to 322 days. Of the 220 merger terminations, 34 were terminated by the target, 56 by the bidder, 40 by a successful bid by a third party and 90 for unknown reasons.

\section{Methodology and Hypotheses}

First, we form portfolios of mergers classified as horizontal, vertical and conglomerate in nature. To do this, we follow Berger and Ofek (1995), Mann and Sicherman (1991), Sicherman and Pettway (1987) and Smith (1990) in using the two-digit SIC code of the two firms involved to classify each proposed merger. If both firms have the same two-digit SIC code, then we classify the attempt as horizontal; if both firms have the same one-digit, but not two-digit SIC codes, then we classify the attempt as vertical; and if each firm has a different one-digit SIC code, we classify the attempt as conglomerate. We double-checked the classification of vertical 
and conglomerate mergers by examining the short description of each firm's business from $10 \mathrm{~K}$ Reports and Annual Reports.

Second, we use standard event-study methodology to calculate portfolio excess returns for our full sample and for the horizontal, vertical and conglomerate sub-samples. We use the market-adjusted return model to calculate abnormal returns:

$$
A R i, t=R i, t-R M, t
$$

where:

$A R i, t$ is the abnormal return for portfolio i on day $\mathrm{t}$,

$R i, t$ is the return for portfolio i on day $\mathrm{t}$, and

$R M, t$ is the market return for the equal-weighted CRSP index on day $\mathrm{t}$.

We choose to employ the market-adjusted model rather than the market model because of the large expected changes in betas for firms involved in takeovers. As a robustness test, we also estimate returns using the standard market model:

$$
A R i, t=R i, t-\left(\beta_{0}+\beta_{1} R M, t\right)
$$

where $A R i, t, R i, t$, and $R M, t$ are as defined above and the intercept and slope coefficients $\beta_{0}$ and $\beta_{1}$ are estimated by ordinary-least-squares regression over the period from 300 to 50 trading days before the merger announcement.

We calculate portfolio cumulative abnormal returns $C A R i$ by summing the portfolio abnormal returns $A R i$ over the three-day event window $-1,0,1$. We calculate portfolio cumulative abnormal returns (CARs) for our entire samples of bidders and targets, and then form separate portfolios of bidders and targets based upon our classifications of mergers as horizontal, vertical or conglomerate. We then test for significant differences in these portfolio CARs. 
According to the synergies hypothesis, we expect to find positive CARs around the bid announcements as shareholders revalue the firm in light of a positive NPV investment; and negative CARs of equal magnitude around the termination announcements as shareholders revalue the firm in light of the loss of that positive NPV investment. In addition, we expect the CARs for conglomerate mergers to be smaller than those for non-conglomerate mergers, as financial synergies are expected to be much smaller than real operating synergies, yielding lower NPVs.

According to the agency hypothesis, we expect to find negative CARs around the bid announcements as shareholders revalue the firm in light of a negative NPV investment; and positive CARs of equal magnitude around the termination announcements as shareholders revalue the firm in light of the cancellation of that negative NPV investment. The agency hypothesis makes no predictions regarding the relative magnitudes of gains/losses of conglomerate versus non-conglomerate firms.

According to the signaling hypothesis, we have no expectations regarding the direction of CARs around the bid announcements, but expect that the CAR reversal around the termination announcement will be significantly smaller in magnitude. This is because managers making positive but unsuccessful NPV bids will be expected to make future positive NPV bids, while managers making negative but unsuccessful NPV bids will be expected to make future negative NPV bids. These expectations lead to a permanent revaluation of the firm beyond the value of the investment project involved in the current bid.

Third, we use eq. (1) and eq. (2) to estimate abnormal returns for each firm in our sample. From these daily abnormal returns, we calculate firm CARs and then will estimate a series of cross-sectional regression model of the form: 


$$
\text { CAR }_{i}=\beta_{0}+\beta_{1} * \text { Horizontal }_{i}+\beta_{2} * \text { Vertical }_{i}+\sum \beta_{N} * \text { Control Variables }_{+} \varepsilon_{i}
$$

where:

$C A R_{i}$ is the cumulative abnormal return around the announcement date for firm i, Horizontal $_{i}$ is a dummy variable indicating horizontal takeover attempts, Vertical $_{i}$ is a dummy variable indicating vertical takeover attempts, Control Variables ${ }_{i}$ are a series of control variables described below, $\beta_{N}, \mathrm{~N}=0$ to $\mathrm{K}$ are parameter estimates, and $\varepsilon_{i}$ is a normally distributed error term.

Based upon the findings of previous research, our proposed control variables include the absolute size of the target, the relative size of the target to the bidder, the type of payment (cash vs. stock vs. combo), and which party terminated the proposed merger (bidder, target, other acquirer, or unknown).

If the synergies hypothesis is correct, then we expect to find positive and significant coefficients for the intercept, as well as for the dummy variables Horizontal and Vertical. If the agency hypothesis is correct, we expect to find a negative and significant coefficient for the intercept and insignificant coefficients for the dummy variables Horizontal and Vertical.

Fourth, we estimate cross-sectional regressions of the form:

CAR-TERM $_{i}=\beta_{0}+\beta_{1} *$ CAR-BID $i+\varepsilon_{i}$

where:

$C A R-$ TERM $_{i}$ is the cumulative abnormal return around the merger termination announcement date for firm i,

$C A R-B I D_{i}$ is the cumulative abnormal return around the merger announcement date for firm i. 
$\beta_{n}, \mathrm{~N}=0$ to 1 are parameter estimates for the intercept and slope, and

$\varepsilon_{i}$ is a normally distributed error term.

If the synergies hypothesis is correct, we expect to find an insignificant intercept and a coefficient of minus one for $C A R-B I D$, as the bid announcement gains are completely reversed at termination. If the agency hypothesis is correct, we expect to find an insignificant intercept and a coefficient of plus one for $C A R-B I D$, as the bid announcement losses are completely reversed at termination. If the signaling hypothesis is correct, then we expect the coefficient of $C A R-B I D$ to be significantly different from one, as shareholders permanently revalue the firm's management team by failing to completely reverse the bid announcement gain at termination.

\section{Results}

Table 3 presents results from estimating cumulative abnormal returns (CARs) using eq. (2). Panel A presents results for the full sample. On average, bidders suffered a negative and statistically significant cumulative abnormal return of 211 basis points during the three-day event window around announcement of the merger bid, but earned back a positive and statistically significant cumulative abnormal return of 81 basis points during the three-day event window around announcement of the merger termination. The average combined return during the two event windows is a statistically significant negative 130 basis points.

Panels B, C and D present results by type of merger, type of payment, and terminating party, respectively. During the bid window, firms engaged in both focusing and diversifying mergers realized negative CARs, but firms announcing horizontal mergers recorded negative CARs that were twice the magnitude of those for vertical or conglomerate mergers. During the termination window, firms engaged in focusing mergers (horizontal and vertical) realized 
positive and marginally significant cumulative abnormal returns while firms engaged in diversifying mergers realized negative but insignificant cumulative abnormal returns.

During the bid window, firms proposing stock transactions realized statistically significant and negative CARs of 424 basis points while firms proposing cash transactions earned positive but statistically insignificant CARs and firms proposing combo transactions earned negative but statistically insignificant CARs. During the termination window, firms proposing cash transactions realized statistically significant and positive CARs of 232 basis points; returns for non-cash transactions were positive but not significantly different from zero.

During the bid window, firms that terminated their own proposals realized statistically significant and negative CARs of 356 basis points, while firms whose targets terminated their proposals realized negative and significant CARs of 221 basis points. Firms that lost out to another successful bidder realized negative and significant CARS of 199 basis points. All other firms recorded negative and significant CARs of 135 basis points. During the termination window, firms that terminated their own proposals earned positive and statistically significant CARs of 308 basis points, while bidders that lost out to another successful bidder earned positive and statistically significant CARs of 242 basis points. Firms whose targets terminated their bids realized positive but insignificant CARs, and "other" firms earned CARs that were negative but insignificant. When CARs for the two event windows are summed together, only firms that lost out to another bidder ended up with net positive returns.

In general, the results in Table 3 are inconsistent with the synergies hypothesis, which predicts positive CARs during the bid-announcement window, but supportive of the agency hypothesis, which predicts negative CARs during the bid-announcement window. During the bid window, each portfolio of firms analyzed realized negative CARs except for those proposing 
cash transactions, which earned positive but insignificant CARs. For many portfolios, the negative CARs are statistically significant. In general, we do observe positive CARs during the termination-announcement window, but the coefficients are much smaller in magnitude than in the bid window, which is inconsistent with the agency hypothesis. These results, are supportive of the signaling hypothesis, which predicts that the reversals during the termination window will be much smaller in magnitude than the declines in the bid window.

Table 4 presents results from estimating eq. (4), which tests for reversal of the bid announcement returns during the time of the termination announcements. These results enable us to test the signaling hypothesis: whether or not the merger proposal itself affects the value of the firm by signaling investors about the quality of management. If the estimated coefficients are significantly greater than -1.0 , then our evidence supports the signaling hypothesis. For the full sample, the coefficient on CAR-Bid is -0.19 , which is significantly higher than -1.0 and is significantly different from zero at the 0.06 significance level. When we examine the results by type of merger, we see that these results are driven by statistically significant results for focusing mergers in general and horizontal mergers in particular. For horizontal mergers, about onefourth of the bid announcement return is reversed at the time of termination. For diversifying mergers, there is no evidence of reversal; in fact, the coefficient on CAR-Bid is positive, but not significantly different from zero.

Overall, these results are broadly supportive of the signaling hypothesis, in that the changes in value realized during the bid announcement window are only partially reversed during the time around the merger termination announcement. The results also are supportive of the synergies hypothesis, in that we find significantly different results for focusing and 
diversifying mergers. The decline in firm value associated with a focusing merger is significantly smaller than that associated with a diversifying merger.

\section{Summary and conclusions}

Our results provide new evidence on the valuation effects of mergers. We contribute to the literature in at least three important areas. First and most important, we will contribute to the literature on signaling by investigating whether a takeover attempt signals investors about the quality of firm management as well as the quality of the specific firm investment under consideration. We find strong and persuasive evidence that the merger proposal itself, as well as the proposed transaction, affects the value of the firm. Our results show that the value of the bidding firm is permanently reduced by the proposal, even when the proposed transaction is not consummated. We interpret this as evidence that firm management has revealed its propensity for undertaking negative NPV projects, and that the market punishes management by lowering its valuation of the firm.

Second, we contribute to the literature on the value of diversification by examining how merger bids and terminations affect the relative values of bidders attempting diversifying and focusing takeovers. Contrary to the synergies hypothesis, we find that firms proposing horizontal mergers realize the greatest negative cumulative abnormal returns and do not recover when the bids are terminated.

Third, we contribute to the literature on the valuation effects of mergers by using data covering the period from the 1991-2000 to re-examine the important topic of who wins and who loses when mergers are terminated. Previous research in this area has exclusively relied upon data from the 1980 s. 
The results of this research are not only important for academic professionals but also have broad implications for corporate managers and other stakeholders, government regulators, and especially investors who rely upon the market for corporate control to discipline managers. Managers and stockholders of both the target and bidding firms want to know how mergers affect the values of their firms. Employees and labor unions are interested in the wealth redistribution effect of the mergers. Government regulators want to know whether mergers concentrate power and lessen competition. Investors, merger arbitrageurs, and portfolio managers can use the results of this research to make better investment decisions, including disciplining managers through the market for corporate control. 


\section{REFERENCES}

Amihud, Y., Dodd, P., and Weinstein, M., 1986 Conglomerate Mergers, Managerial Motives, and Stockholder Wealth, Journal of Banking and Finance 10, 401-410.

Amihud, Y., and Lev, B., 1981, Risk Reduction as a Managerial Motive for Conglomerate Mergers, Bell Journal of Economics 12, 605-617.

Asquith, P., 1983, Merger Bids, Uncertainty, and Stockholder Returns, Journal of Financial Economics 11, 51-83.

Baker, G., Jensen, M., and Murphy, K., 1988, Compensation and Incentives: Practice vs. Theory, The Journal of Finance 43, 593-616.

Berger, P., and Ofek, E., 1995, Diversification's Effect on Firm Value, Journal of Financial Economics 37, 39-65.

Bhagat, S., Shleifer, A., Vishny, R., 1990, Hostile Takeovers in the 1980s: The Return to Corporate Specialization, Brookings Papers on Economic Activity, 1-72.

Bradley, M., 1980, Interfirm Tender Offers and the Market for Corporate Control, Journal of Business 53, 345-376.

Bradley, M., Desai, A., and Kim, E., 1988, Synergistic Gains from Corporate Acquisitions and Their Division Between the Stockholders of Target and Acquiring Firms, Journal of Financial Economics 21, 3-40.

Bruner, Robert F., 2002, Does M\&A Pay? A Survey of Evidence for the Decision Maker, Journal of Applied Corporate Finance 12, 48-68

Chang, S., and Suk, D. 1998, Failed Takeovers, Methods of Payment, and Bidder Returns, The Financial Review 33, 19-32.

Comment, R., and Jarrell, G., 1995, Corporate Focus and Stock Returns, Journal of Financial Economics 37, 67-87.

Davidson, W., Dutia, D., and Cheng, L., 1989, A Re-examination of the Market Reactions to Failed Mergers, The Journal of Finance 44, 1077-1083.

DeLong, G., 2001, Stockholder Gains from Focusing versus Diversifying Bank Mergers, Journal of Financial Economics 59, 221-252.

Denis, D., and Serrano, J., 1996, Active Investors and Management Turnover Following Unsuccessful Control Contests, Journal of Financial Economics 40, 239-266. 
Dodd, P., and Ruback, R., 1977, Tender Offers and Stock Returns: An Empirical Analysis, Journal of Financial Economics 5, 351-374.

Dodd, P., 1980, Merger Proposals, Management Discretion and Stockholder Wealth, Journal of Financial Economics 8, 105-137.

Dodd, P., and Warner, J., 1983, On Corporate Governance: A Study of Proxy Contents, Journal of Financial Economics 11, 401-438.

Eckbo, B., 1983, Horizontal Mergers, Collusion, and Stockholder Wealth, Journal of Financial Economics 11, 241-274.

Healy, P., Palepu, K., Ruback, R., 1992, Does Corporate Performance Improve After Mergers? Journal of Financial Economics 31, 135-176.

Jensen, M., and Murphy, K., 1990, Performance pay and top-management incentives, Journal of Political Economy 98, 225-264.

Lang, L., Stulz, R., 1994, Tobin's Q, Corporate Diversification and Firm Performance, Journal of Political Economy 102, 1248-1280.

Lang, L., Stulz, R., and Walking, R., 1989, Managerial Performance, Tobin's Q, and the Gains from Successful Tender Offers, Journal of Financial Economics 24, 137-154.

Lang, L., Stulz, R., and Walking, R., 1991, A Test of the Free Cash Flow Hypothesis: The Case of Bidder Returns, Journal of Financial Economics 29, 315-336

Levy, H., and Sarnat, M., 1970, Diversification, Portfolio Analysis and the Uneasy Case for Conglomerate Mergers, The Journal of Finance 25, 795-802.

Lewellen, W., 1971, A Pure Financial Rationale for the Conglomerate Merger, The Journal of Finance 26, 521-537.

Mann, S., and Sicherman , N., 1991, The Agency Costs of Free Cash Flow: Acquisition Activity and Equity Issues Journal of Business 13, 213-227

Megginson W., Morgan A., Nail L., 1997,Corporate Focus and Corporate Acquisitions: Theory and Evidence, Working Paper, University of Georgia.

Maquieria, C., Megginson, W., and Nail, J., 1998, Wealth Creation versus Wealth Redistribution in Pure Stock-for-Stock Mergers, Journal of Financial Economics 48, 3-33.

Morck, R., Shleifer, A., and Vishny, R., 1990, Do Managerial Objectives Drive Bad Acquisitions? The Journal of Finance 45, 31-48. 
Safieddine, A., and Titman, S., 1999, Leverage and Corporate Performance: Evidence from Unsuccessful Takeovers, The Journal of Finance 54, 547-580.

Servaes, H., 1996, The Value of Diversification During the Conglomerate Merger Wave, The Journal of Finance 51, 1201-1225.

Sicherman, N., and Pettway, R., 1987, Acquisition of Divested Assets and Shareholder Wealth. Journal of Finance 42, 1261-1273.

Smith, A., 1990, Corporate Ownership Structure and Performance, Journal of Financial Economics 27, 143-169.

Stapleton, R., 1982, Mergers, Debt Capacity, and the Valuation of Corporate Loans, in Keenan, M., White, L.J. (Eds.) Mergers and Acquisitions, Chapter 2. D.C. Heath, Lexington, MA.

Weston, F., Mansinghka, S., 1971, Tests of the Efficiency Performance of Conglomerate Firms, The Journal of Finance 42, 943-963.

Williamson, O., 1975, Markets and Hierarchies: Analysis and Antitrust Implications. Free Press, New York. 
Table 1:

Annual Distribution of 220 Announcements of Terminated Mergers from 1991-2000

Panel A: By Type of Merger

$\begin{array}{lrrrr}\text { Year } & \text { Horizontal } & \text { Vertical } & \text { Conglomerate } & \text { All } \\ 1991 & & & 0 & 10 \\ 1992 & 8 & 2 & 1 & 8 \\ 1993 & 5 & 2 & 0 & 8 \\ 1994 & 8 & 0 & 5 & 30 \\ 1995 & 17 & 8 & 2 & 21 \\ 1996 & 14 & 5 & 6 & 26 \\ 1997 & 16 & 4 & 6 & 27 \\ 1998 & 12 & 9 & 7 & 33 \\ 1999 & 13 & 13 & 4 & 39 \\ 2000 & 22 & 13 & 4 & 18 \\ & 12 & 2 & & \\ \text { Total } & & & 35 & 220\end{array}$

Panel B: By Method of Payment

$\begin{array}{rrrrr}\text { Year } & \text { Stock } & \text { Cash } & \text { Combo } & \text { All } \\ 1991 & 4 & 2 & 4 & 10 \\ 1992 & 3 & 0 & 5 & 8 \\ 1993 & 4 & 1 & 3 & 8 \\ 1994 & 12 & 10 & 8 & 30 \\ 1995 & 8 & 5 & 8 & 21 \\ 1996 & 12 & 2 & 12 & 26 \\ 1997 & 9 & 9 & 9 & 27 \\ 1998 & 19 & 9 & 5 & 33 \\ 1999 & 20 & 9 & 10 & 39 \\ 2000 & 11 & 5 & 2 & 18 \\ & & & & \\ \text { Total } & 102 & 52 & 66 & 220\end{array}$


Table 2:

Sample Distribution and Descriptive Statistics

for 220 Terminated Mergers from 1991-2000

$\begin{array}{lrr} & \text { N. Obs. } & \text { Mean } \\ & 220 & 1.594 \\ \text { Value } & 220 & 0.798 \\ \text { Relative Size } & & \\ & & \\ \text { Payment: } & 52 & 0.24 \\ \text { Cash } & 66 & 0.30 \\ \text { Combo } & 102 & 0.46 \\ \text { Stock } & & \\ & & \\ \text { Type: } & 127 & 0.58 \\ \text { Horizontal } & 58 & 0.26 \\ \text { Vertical } & 35 & 0.16 \\ \text { Conglomerate } & & \\ & & \\ \text { Terminated: } & & \\ \text { By Target } & 34 & 0.15 \\ \text { By Bidder } & 56 & 0.25 \\ \text { By }{ }^{\text {rd }} & 40 & 0.18 \\ \text { By Other } & 90 & 0.41\end{array}$

Std.

Error

0.367

0.16

Payment:

Cash

.24

0.46

Stock

.26

.16

Terminated

By Target

0.15

By Bidder

0.18

By Other

0.41 
Table 3:

Three-Day Cumulative Abnormal Returns for 220 Bidding Firms

Around the Announcement of Merger Terminations from 1991-2000

Bid

$$
\text { N. Obs. } \quad \operatorname{CAR}(-1,1) \quad \text { T-Stat }
$$

Termination

CAR(-1, 1) T-Stat

Panel A: Full Sample

All

220

$-2.107$

$-4.6$

$* * *$

0.811

$2.19 * *$

Panel B: By Method of Payment

Cash

Combo

Stock

$\begin{array}{rr}0.502 & 0.41 \\ -0.875 & -1.15 \\ -4.235 & -5.89\end{array}$

2.315

0.120

2.62

0.492

0.57

102

$-4.235$

$-5.89$

Panel C: By Terminating Party

Bidder

Target

Third

Other

Panel D: By Type of Merger

Horizontal

Vertical

Conglomerate

56

34

40

90

127

58

35
$-3.55$

$-2.208$

$-1.986$

$-1.34$

$-2.616$

$-1.495$

$-1.277$
$-3.07 * * *$

$-2.26 * *$

$-1.81 *$

$-2.20 * *$

$-5.05 * * *$

$-1.63$

$-0.58$
3.082

0.502

2.417

$-1.198$

0.577

2.174

$-0.597$
$2.05 * *$

0.48

$3.29 * * *$

0.14 


\section{Table 4:}

Reversal of Bid Announcement Returns by Termination Announcement Returns

Results from estimating the cumulative abnormal returns during the three-day event window around the announcement of a merger termination as a function of the cumulative abnormal returns during the three-day event window around the announcement of a merger bid.

Panel A:

$$
\text { Coefficient T-Statistic Adjusted R2 }
$$

All Firms

$\begin{array}{lrrrr}\text { Intercept } & 0.004 & 0.45 & & \\ \text { CAR-Bid } & -0.196 & -1.91 * & 0.012\end{array}$

Panel B:

By Type of Merger

Horizontal

Intercept

$-0.0012-0.10$

CAR-Bid

Vertical

Intercept

0.0179

CAR-Bid

$-.256$

$-1.09$

0.003

Conglomerate

Intercept

$-0.004$

$-0.23$

CAR-Bid

0.163

0.80

$-0.011$

Non-

Conglomerate

Intercept

0.0049

0.49

CAR-Bid

$-0.260$

$-2.25 * *$

$0.0215 * *$ 